\title{
JU
}

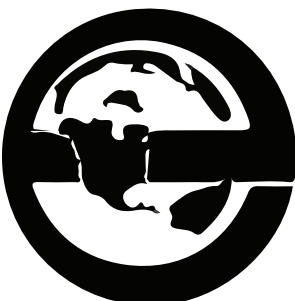

The Journal for Undergraduate Ethnography

Volume 6 | Issue 2

ISSN 2369-8721

\section{Freedom and Emptiness: Investigating the Experience of Meaning-Making among Non-Religious Students}

\author{
Alex Popper \& Femke van Hout \\ University College Maastricht, alex.popper@hotmail.com, \\ femkevanhout@hotmail.com
}

\section{ABSTRACT}

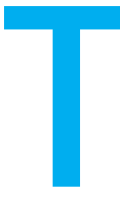

his paper investigates the experience of university students who identify as non-religious. Drawing on the philosophical frameworks of Nietzsche's notion of nihilism and Sartre's ideas on Atheist Existentialism, the research explores how non-religious

students experience and give meaning to their non-religiosity. Ten in-depth interviews were conducted with students aged 18-25. According to the interviewees, being non-religious means that a God or a predetermined purpose in life does not exist. From this perspective, inner tensions arise, each encompassing feelings of freedom and empowerment as well as feelings of emptiness and heaviness. The article explores three main themes from the interview material, which relate to Sartre's notions of freedom and abandonment. The first focuses on the tension between freedom and emptiness: in the absence of a god, individuals can create the life that they themselves will, which allows them a great sense of empowerment and responsibility. However, for many, this also results in feelings of emptiness and despair. The second theme discusses the participants' value of their own sense of critical awareness in contrast to a certain longing for the blissful ignorance that religion, in their eyes, provides. Finally, the tension between participant's concept of 'nothing out there' and the existence of 'something' is explored. This research draws on philosophical theories of meaning-making to illuminate ethnographic accounts of the lived experiences of non-religious individuals, thereby contributing to the anthropology of religion and belief, as well as philosophy and other fields closely concerned with processes of meaning-making. 
"At one moment, we understand our situation as one of high

trage-dy, alone in a silent universe, without intrinsic meaning,

condemned to create value." (Taylor 1992, 68)

In contemporary society, the significance of religion has considerably decreased (Taylor 2007). During the Enlightenment period in the 18th century, when science and rationality gained considerable influence in the public sphere, religion began to no longer hold the same authority as it had before (Bruce \& Glendinning 2010; Uskoković 2010). With the shift away from an idea of an absolute God, the influence of Christian values and the promise of life after death declined. According to the German philosopher Friedrich Nietzsche, this could ultimately result in nihilism: the denial of any values, truth or purpose in life (Auxier 1987; Hatab 1987). However, Nietzsche himself did not reject the existence of any value in the world. Nihilism, he stated, is something that we must overcome. A strong morality should not be imposed on the individual by an external force, but can be developed within oneself, and can be found within the very will to live (Hatab 1987). This idea of 'overcoming' nihilism is what led us to our research project of deconstructing how students who identify as non-religious find their sense of meaning in the absence of a God or other pre-determined purpose.

Our study developed into an investigation of how students (aged 18-25) who identify as non-religious relate to the meaning and consequences of this non-religiosity. What does it mean to be non-religious? How do non-religious students relate to the idea that God does not exist? How do they find or look for a sense of purpose in life? As the research progressed, three main themes emerged, all of which can be connected to Jean-Paul Sartre's notions of freedom and abandonment in the absence of God,and are further supported by Charles Taylor's emphasis on the lived experiences of individuals within contemporary secular society (Sartre 2007; Taylor, 2007).
Through this research it be-came apparent that religiosity and non-religiosity do not exist in a state of oppositional rivalry. Rather, they result in different lived experiences that are often filled with tensions and contradictions. After placing our research in its social and historical context, this article will delve into these themes and the tensions that arose in the understanding of the individual's experiences of non-religiosity.

\section{Enlightenment, Nihilism and Existentialism}

In his book 'A Secular Age' (2007), Charles Taylor investigates the background and social context in which people develop a sense of meaning or purpose in life. According to Taylor, we have moved from a society in which religion seemed almost 'naturally' interconnected with people's daily and public activities toward a society in which religion is experienced as just one of the many ways we can give meaning to the world around us. The predominant narrative about the movement from a religious to a secular society is one of substitution (Taylor 2007). From 1500 onwards, traditional religious systems, which were built around the idea of the Christian God, were challenged by the development of science and by the increasingly valued 'sovereignty of the individual' (Manschreck 1976). The emergence of Protestantism in the 16th Century challenged the old system by emphasizing the importance of the individual's relationship with God, marking the beginning of a long period of criticisms of traditional, religious and dogmatic systems (Manschreck 1976). This development led to the Enlightenment, often considered as the greatest leap forward in the creation of a 'better', more rational humanity (Israel 2006; McGrath 2006). At this time, empirical science broke through as the 'true way' of finding knowledge (Israel 2006). Skepticism and a critical stance towards religion, together with reflective self-awareness, were fiercely promoted among scientists, philosophers and intel-lectuals (O’Brien 2010). As a consequenceof these ideals, 
religion was increasingly seen as a failure, keep-ing humanity ignorant with its coercive, dogmatic prescriptions (Manschreck 1976).

All in all, a predominant idea is that science came into existence, gave people the means to discover the world as it truly is, and freed them from the illusions of blind faith. Taylor, however, nuances this argument, understanding the secularization of modern society rather as a development in which various advances of human understanding - not only in the natural sciences, but also in philosophy, art and literature - gave people a different understanding of what it means to be human. In a way, these developments led to a new 'toolbox' with which people could develop a humanistic account of a meaningful life without resorting to the notion of a god (Taylor 2007).

Today, this perceived contradiction between the critical, selfaware individual and the dogmatic, faithful believer is still very present. While religion is often seen as an external force that promotes blind faith in a 'supernatural' power, the development of values and meaning from within oneself, by thinking and reflecting critically, has become increasingly important in contemporary society (Martel-Reny 2014). According to Taylor (2007), there exists the idea that modern civilization, in which the free individual can flourish, cannot but bring about the end of the religious era. Indeed, more and more people define themselves as atheists (Goodman and Mueller 2009). Whereas 'theism' means 'belief in a God or gods', atheism as its antithesis denies the existence of God or any other supernatural power (Goodman and Mueller 2009).

What, then, does it mean to live in a secular society? Taylor (2007) argues that secularism can be understood in three different ways. Firstly, religion is no longer inseparable from the social sphere: when we carry out activities in public spaces, the norms, values and principles that guide us no longer necessarily refer to God or any other religious belief. One could, for instance, enter the realm of politics without believing in God. Secondly, secularity can be understood as a decrease in the number of people engaging in religious belief and practice. Thirdly, secularity entails a move from a society in which the existence of God is an unquestioned aspect of human life, towards a society in which religion is just one way of living among other alternatives. In this sense, secularity incorporates the whole social and private context in which the development of our moral, spiritual and religious understanding and search takes place (Taylor 2007). Our research focuses on this third aspect: the lived experience of non-religiosity and the alternative ways of meaning-making that non-religious students develop. According to Taylor, non-religiosity could lead to the development of more humanistic spiritual experiences, but could also lead to feelings of meaninglessness and purposelessness (Taylor 2007).

This latter idea was previously articulated by Friedrich Nietzsche, who, at the end of the 19th century, boldly celebrated the death of God (Manschreck, 1976; Nietzsche, 2010). Together with our belief in God, he stated, we must also bury all Christian values and ideals of love, pity and kindness, for they lost their credibility at the same moment God was murdered (Auxier 1987; Nietzsche 2010). The loss of this moral value system can result in the idea, in Dostoevsky's words, that, "If God does not exist, then everything is permitted" (Manschreck 1976, 87). Furthermore, if one does not believe in God, the idea that there is a heaven or a life after death suddenly becomes severely implausible. Everything a human being does, creates or achieves will be lost when he or she dies. According to Nietzsche, the death of God can result in nihilism: the paralyzing belief that there exists no absolute value, truth or any purpose in the world (Manschreck 1976; Auxier 1987). In their article on atheist students, Goodman and Mueller state that this link between nihilism and the absence of God is still present. Atheism, they argue, is often associated with nihilist ideas, being "characterized as a dark force that rejects the values of goodness, morality and purpose" (Goodman and Mueller 2009, 56). 
Jean-Paul Sartre's introduction of the notions of freedom, aban-donment and despair offers an additional perspective to these questions of human existence in the absence of God. Greatly influ-enced by the ideas of Nietzsche, Sartre discusses the consequences of 'the death of God' in his essay 'Existentialism is a Humanism' (2007). According to Sartre, the idea that God does not exist will result in the ultimate freedom of the individual subject. In order to clarify this, Sartre first explains how a knife is manufactured. When making a knife, one already knows what kind of purpose it will serve once it exists. In this way, for the knife, essence precedes existence. If God existed, human beings would not differ from the knife inasmuch as they would be created according to a certain concept, in order to serve a definite purpose on earth. Howev-er, Sartre states, God does not exist. Therefore, humankind has no fixed nature or purpose, nor is it created by anybody; human beings are ultimately free. Existence precedes essence, that is, a human first encounters the world and him- or herself, lives and creates, before s/he becomes something (Sartre 2007).

Furthermore, a human being is not an object but a subject, and can never transcend this subjectivity. While some critics argue that calling humans 'subjects' deprives them of dignity, Sartre states exactly the opposite. It is exactly this subjectivity that makes human beings different from objects, and exactly this subjectivity that makes a human ultimately free and responsible for what s/he is (Sartre 2007; Fischer 2016). If there is no God, "man is nothing other than what he makes of himself " (Sartre 2007, 22). How-ever, together with experiencing ultimate freedom, humankind feels abandoned and empty if there is no God or higher power. As Sartre states that humans' freedom cannot be absolutely tied to anything, such as religion or politics, this freedom automatically involves a sense of emptiness, of not belonging anywhere (Man-schreck 1976). Sartre's ideas on atheist existentialism were reflect-ed time and time again in the material we gathered in the interviews. Therefore, we have used Sartre's philosophy as a framework for our analysis as we delve into the lived experienceof non-religious students.
Apart from the idea that non-religiosity can have nihilism, or feelings of emptiness and abandonment, as its consequences, many studies argue that it can also inspire 'new' searches for meaning and purpose in life. The secularization of society and the shift toward an individualistic society brought about new trends among individuals identifying with other spheres of spirituality and alternative ways of meaning-making. In our study, spirituality refers to a search for meaning in which one experiences something 'deeper' than everyday life. While spirituality could be connected to religious experiences, it can also stand in contrast to mainstream, traditional forms of religion. While spirituality focuses mostly on the inner experience and authorization of the individual, religion is sometimes seen as externally imposed and dogmatic (Vincett and Woodhead 2009). The term 'spiritual' in today's society is closely associated with notions of the autonomous subject, freedom, and empowerment, aspects that became central themes throughout our research and are very much linked to Sartre's notion of the free individual.

Religious studies scholar Martel-Reny (2014) investigates the meaning-making experiences of adolescents in Quebec, and their definitions of and personal relations with religion and spirituality. As Martel-Reny describes, the participants of the study "saw a difference between religion and spirituality - the former as a structuring force that curtailed individual freedoms, the latter as an elective and private choice that is free from the dogmatic taint and power struggles they associated with religion" (Martel-Reny 2014, 185) In Martel-Reny's research it was assumed that the meaning making activities and convictions of adolescents who iden-tified as non-religious were automatically spiritual. However, we did not want to approach our research with the assumption that all nonreligious processes of finding meaning would necessarily be of a spiritual nature. Rather, we also focused on the everyday lives of non-religious students, such as love of music, relationships with their friends, or sense of belonging to community. 
The findings of Day's (2009) three-year case study investigating mainstream religious belief in Euro-American countries supported our hypothesis. This research showed that participants' construction of beliefs were mainly rooted in their personal relationships. Day's findings call for a closer look into the forces of meaning in the everyday lives of young adults, and "such a shift necessitates a relocation of the transcendent to the everyday and social" (Day 2009, 1). This study highlighted the need to probe more deeply into the everyday experiences, and personal relation-ships of our participants rather than only asking explicitly philo-sophical questions in the interviews.

The focus on alternative ways of making meaning is further illuminated in Taylor's writing on 'The Ethics of Authenticity' (1992). Taylor states that the excessive individualism originating from the 18th century Enlightenment does not necessarily result in meaninglessness and purposelessness, but can also inspire people to start looking for moral 'authenticity'. In a way, individualism and the 'death of God' have resulted in the idea that people have the freedom to determine their values and morals themselves. This led to a feeling that became deeply rooted in modern consciousness: that every human being has his or her own way of being human (Taylor 1992). This ties in with the idea that 'every individual should have agency to give meaning to life in his or her own way', an idea that gained significance in the 1970s with the emergence of the New Age spiritual movement (Vincett and Woodhead 2009). This trend can be regarded as congruent with the emer-gence postmodernist consumer society, in that people practice a certain 'religion shopping' and combine religious notions with ideas emerging in the natural or social sciences. In a way, peo-ple create their own sense of meaning and "use, recycle, combine and adapt existing religious ideas and practices that they see fit" (Hanegraaff 2009, 340).
In our research it became apparent that while the absence of any prescribed or pre-determined meaning in life could result in nihilism, it could also result in a sense of empowerment and freedom. When the external world imposes no values on people, they are free to create their own sense of authenticity, selfhood, and path in life (Taylor 1992).

\section{Methodology}

Our ethnographic research consisted of ten in-depth interviews with students from Maastricht University aged between 18 and 25 who identify as non-religious. The participants were recruited through acquaintances and a message posted on a Facebook group of the University. Some volunteered whilst others were asked to participate. All came from educated backgrounds and were pursuing either their Bachelor's or Master's degree at the faculties of Law or Medicine, the Conservatorium, University College Maastricht, or the School of Business and Economics. The participants were raised in different countries, and came from a variety of religious and non-religious backgrounds. The interviews lasted between one and two hours and, with the participants' consent, were recorded using a digital sound recorder.

We chose to interview students of this age range as this life period is often experienced as a time of significant transition. Student life is typically perceived as a time of heightened independence and freedom in comparison to other life stages. At this time, as we have observed and experienced, questions arise about oneself, the surrounding world and one's place within the world.

We used the in-depth interview approach as it allowed us to gain access to the personal experiences of the participants. The nature of the semi-structured interview gave the interview a somewhat informal tone, which gave both interviewees and interviewers a certain sense of freedom while talking about personal topics (Hesse-Biber 2014). The interview questions focused on the participant's religious or non-religious background, their sense of values and morals, moments/feelings of purpose in their lives, and 
their reflections on death. In order to protect the identities of the interviewees, the names used throughout the article are pseudonyms.

After carrying out and transcribing the interviews, we began drawing out their recurring patterns. Once these were identified, we undertook a process of clustering and coding the patterns into a broader framework of umbrella themes. These themes were then developed in memos (Hesse-Biber 2014) as we reflected upon each theme in connection with our secondary sources, analyzing the relations of the themes with one another through a series of mind-maps.

Furthermore, as researchers we interviewed one another in order to understand our own position within the research, our views and personal experiences, whilst also having the opportunity to reflect how appropriate our questions were. Understanding and reflecting upon our own processes of meaning-making strengthened our deep interest and engagement with the research, whilst also illuminating the significance of our own subjective positioning in the role of researchers. We treated this data as we did the data from our other participants, including them in our material for analysis.

\section{Being Non-religious: the Tension between Freedom and} Emptiness

"We are condemned to be free." (Sartre 2007, 29)

Since all the interviewees identified as being non-religious, the conversations often focused intensely on the meaning they gave to this non-religiosity. In the participants' eyes, being non-religious mainly involved the conviction that God or any other gods did not exist and that therefore, there was no clear, predetermined purpose in life. Although some of the interviewees defined themselves as spiritual, or speculated about the existence of 'something else' in life, they emphasized that they did not tie these beliefs or
Interestingly, these ideas about non-religiosity led to two main experiences. On one hand, many participants stated that the absence of any God or a definite goal in life gave them a feeling of ultimate freedom, resulting in the experience of a certain empowerment. On the other hand, a feeling of emptiness or loneliness was often emphasized, for the idea that there was 'nothing', or at least no greater being looking after them, resulted in a feeling of being ultimately alone. It should be noted, however, that none of our interviewees felt either free or empty, empowered or lonely. It was exactly the interplay between these feelings and convictions that made this tension between freedom and emptiness in relation to non-religiosity so interesting. One of the interviewees, Franceska (21), described how her stance towards religion had changed over time. Growing up in the Netherlands in a family in which religion, spirituality and agnosticism were all present, she stated that although she used to be religious as a child, she changed her views when someone close to her died. In a way, she discovered that she no longer needed this idea of a God or an afterlife in order to enjoy life and find a sense of meaning in it. In her interview, she put a lot of emphasis on individual freedom, although on the other hand, she stated that the idea that there is nothing after death sometimes scares her.

The very funny thing... that there was nothing there anymore looking after you, or that there was no life after death made me feel really free or something, in a strange way... like "oh I could make my own thing of this! I don't have a purpose in life I just make it myself!" And sometimes the idea that there isn't anything after death really scares me because I think about nothing and I cannot know what nothing is... I think it's really difficult for everyone, secretly, to imagine what nothing is, than to imagine was something is. Because we know what something is, and nothing is just so scary, it's incomprehensible because we never encountered absolutely nothing in our lives, because life is something in itself. 
In this quote, the tension between 'freedom' and 'the incomprehensibility of nothing' is very explicit. On one hand, Franceska says that the idea that there is 'no one' or no life after death 'frees' her in a way, for she has the chance to create her own sense of purpose and meaning. On the other hand, she states that there is "nothing there anymore looking after you", implicitly reflecting on a certain feeling of abandonment. The idea of 'not knowing' what 'nothing' is scares her, because it is an idea impossible to comprehend. In the later section entitled 'Something and Nothing', we will delve more deeply into the participants' stance towards the idea of nothingness.

Interestingly, Franceska uses the word 'make' in order to describe her search for a purpose, which suggests an active stance towards her way of living and personal development. Whereas 'looking' for a purpose would imply the idea that one could 'find' an already determined goal or meaning, 'making' a purpose emphasizes the idea that one can create one's own sense of being. This idea was also emphasized by other interviewees. For instance, Lia (19) who was raised in a Christian family in Palestine, stated that although you never know where and how you will end up, you very much 'shape' your own life. These ideas relate to Sartre's view that, for human beings, existence precedes essence. If God does not exist, "man is nothing but what he makes of himself" (Sartre 2007, 29). The consequence of having ultimate freedom comes with a large responsibility: a person is left to create him- or herself and is therefore also entirely responsible for what he or she is.

The importance of this responsibility was emphasized by Amanda (22). Amanda was born in Bulgaria and had, together with her parents, developed a rather critical stance towards religion. Religion, she said, can result in the transfer of responsibility to something else.
To a certain extent I feel that religious movements... especially with monotheistic religions... they kind of... it's a bit of a transfer of responsibility to something else. It's like: "I had a terrible day or someone died, it's God's act and I don't have to deal with it."

This notion of 'God's act' recurred in many participants' responses in relation to this sense of blame. However, as Amanda went on to explain, the transference of responsibility to God is also a transference of power. As with many other participants, she described feeling responsible for her own actions and life as a source of empowerment: to be responsible is to be free, and vice versa.

It's an act of a person, it's not an act of God. It's as simple as that. You can do whatever you want, and that's what I choose to do... I'm just trying to be a person, not just an automated human being. It's good to be a person right here, right now.

In this quote, she clearly states that an 'act of God' does not exist, only an act of humanity. Interestingly, she then rephrases what Nietzsche and Dostoevsky stated about the consequences of God's death as she says: if God is not there, "you can do whatever you want" (Manschreck 1979). According to Sartre (2007), this is the starting point of existentialism. Instead of turning toward a nihilistic view, Amanda goes from God's non-existence to a sense of empowerment, by stating that she does what she chooses to do. In this choice, her responsibility and her freedom exist simultaneously. This feeling that meaning can be found in freedom of choice is embodied in the words of Taylor: "It seems that significance can be conferred by choice, by making my life an exercise of freedom, even when all other sources fail" (Taylor 1992, 29). Even when life has no intrinsic meaning, we can create meaning through the exercise of our free choice. 
Furthermore, the fact that she speaks about being a 'person' and not just an 'automated human being' can be linked to Sartre's notions of human subjectivity and free will. Human beings, he states, are in contrast to objects free to be what they will themselves to be. This idea that human beings have a free will can be attributed to the individualism very much present in Western societies, influenced by Enlightenment ideals about free will and critical awareness of oneself (Vincett and Woodhead 2009; Manschreck 1976).

However, although freedom, individual choice, and responsibility were often mentioned and elaborated upon, the idea that there was no God or purpose was also described as a source of fear and abandonment. Franceska, for instance, suggested not only that there may be no purpose to be found, but also that perhaps, in the absence of God or a greater purpose, creating this purpose is futile in itself.

So in a way it's really scary, because if there is nothing there or no purpose then you are just looking at a blank page. And you don't even have to write it, you can just go on staring and that's a very scary thing...

By using the 'blank page' metaphor, she makes clear that there is no ready-written story, no clear purpose for people who do not believe in God. Furthermore, they do not even have to 'write' their life story, for there is nobody out there who cares whether you do or not. Rather than a feeling of empowerment, she reflects a feeling of ultimate futility.

Damien (20) grew up in an American, Catholic/Jewish family in Hong Kong, and identifies as a strong atheist. He stated that although he knows that God does not exist, he would prefer to be religious, for if there is no God, "you struggle because you only have yourself". Whilst Damien once held a very negative stance on religion, he now experiences a certain longing for the sense of relief that he perceives religion as providing.
And then I decided I'm a full on atheist, I don't believe in any religion, there is no use in it. I thought to myself: there is no reason for me to be religious, God doesn't exist. But now, my view on religion has kind of changed. I wish I were religious but I can't be. Because... I don't believe in it, but I can understand how people that have a faith in a God benefit more than people that don't believe in a God. Because if stuff gets hard for people that aren't religious, they're alone, they have nothing to turn to. But if you're religious and something is going on in your life, you can say: "oh, I'll look up to the sky and hope that God is there and heave a sigh of relief." But if you have absolutely no belief in a God, that sigh of relief isn't there. Then what do you do? So... yeah.

Damien's change of view on religion reflects what Sartre described in his notion of despair and abandonment in an interesting way. Without God, non-religious people find themselves in a state of loneliness, unable to experience this 'sigh of relief', or the idea of a purpose provided by the divine. Later in the interview, Damien said that the absence of a definite purpose causes a feeling of emptiness. This is what Taylor describes as the possible negative slope of non-religiosity: the experience of an absence, or exile, in which we melancholically long for belief, but we cannot possibly believe anymore. "What dominates is a sense of damnation, of deserved and decided exclusion forever from fullness" (Taylor 2007, 6).

Sartre, too, writes about this negative slope. The idea that God does not exist is in his eyes "severely disturbing" for the individual, for there are no a priori values to be found, neither is there the promise of a life after death. Man stands, in this way, completely alone. "Indeed," Sartre states, "everything is permissible if God does not exist, and man is consequently abandoned, because he cannot find anything to rely on" (Sartre 2007, 29). This quote strongly represents Damien's view that if you are non-religious, "you have no one to turn to". 
All in all, the internal tension between 'freedom' and 'emptiness' that our participants explicitly and implicitly describe, is perhaps best summarized in Sartre's famous words: "man is condemned to be free" (Sartre 2007, 29). Freedom is often perceived as having a positive connotation, empowering the individual being. However, the responsibility for one's own being can also result in a feeling of unbearable heaviness and abandonment. In that way, for many, being free was considered a curse as well as a blessing.

\section{Critical Thinking versus Ignorance}

The idea of freedom also related to the participants' evaluation of critical thinking, in which a similar duality between empowerment and heaviness came about. Throughout the interviews, all of the participants reflected on the importance of critical thinking, valuing their ability to critically analyze religion and belief, the world around them, and themselves. There was often a strong sense of pride in their achievements as they expressed their sense of autonomy to actively reflect upon their own and others' beliefs. We discovered that the familial context had a significant influence on the value that participants attached to this critical thinking. All of the interviewees' parents were either non-religious, or encouraged the participants' own explorations of religion and beliefs. This realization helped us to understand the participants' sense of personal development and the beliefs that they now hold. They often stated that they were proud of their parents' openness or grateful that they were given the freedom to develop themselves freely. This pride and gratitude further underlines how the interviewees felt free to develop their own sense of meaning. Rather than having a dogmatic view externally imposed on them by their parents, they were allowed and supported to develop their own critical stance towards religious belief and identification.
Many participants stated that through thinking critically, they were able to see more widely and deeply than those who followed religious beliefs. In the eyes of most of the interviewees, religion was very much associated with dogmatic beliefs and the promotion of ignorance, hindering the development of the critical individual. Linked to this idea of religion as dogmatic is the perspective that religions are static and absolute. For instance, Alexander (25), who grew up in a Finnish non-religious family, reflected on his ideas that religions, due to their self-acclaimed divinity, were not as prone to changing their ideas as what he calls intellectual ideologies' would be.

Religion is different from other ideologies, because most religions have this self-acclaimed divinity, so that they are correct, they are the truth. Religion is always absolute. I mean, most religions. (...) Whatever your interpretation is, it is more difficult to change your mind if you think you are fulfilling the word of God. It is more difficult to let go of this. It is possible to change it, but it's more extra effort. Other ideologies are different, for instance, socialism... People who came up with socialism are aware that it is a theory about society. And when you change this theory, you are not changing the word of God or divine things, you are just changing a theory, an intellectual thing. It's more self-aware, it is an intellectual concept. And religion doesn't have that. It's a divine source.

Here, Alexander speaks of the difference between religions and 'other ideologies', such as socialism. According to him, 'intellectual ideologies' are more self-aware than religion, for they rely on theories instead of a 'divine source'. He believes that it is difficult to change one's claims if they are considered to be the word of God; to change them would indirectly imply that God was wrong. Later in the interview, he also states that religious people tend to ignore 'proof' or 'facts' that oppose their God-based worldview. This idea 
was linked to all of the participants' responses that reflected the relevance of scientific value in contemporary society, which has been on the rise since the Enlightenment (McGrath 2006; Bruce \& Glendinning 2010; Uskoković 2010). Science was perceived as the antithesis of religion, as it is seen to be based on human reason and empirical evidence rather than blind faith. They spoke of reading a vast array of literature, such as Dawkins' book on The God Delusion, or other sources in which religions were challenged by atheists or scientists. Reason, in this sense, is perceived as being necessarily connected to atheism and the challenge to dogmatic belief systems represented by historical figures such as Copernicus, Darwin and Freud (Taylor 2007).

Moreover, some participants made a direct link between 'being intelligent' and being an atheist. They implied that it was impossible to be both critically reflective and religious because scientific proof or rational thoughts often spoke against religious convictions. In this way, our non-religious participants viewed themselves as having more of an objective stance towards the world around them than religious persons, a notion which could have its origin in Enlightenment ideals (Manschreck 1976; McGrath 2006).

Science was in the 18th century already celebrated as the 'Promethean liberator of humanity' from religion (McGrath 2006), yet it seems as if for our interviewees, this connection between scientific thinking and the liberation of the individual is still very much present. Essentially, this value of critical thinking is linked to Sartre's notion of freedom and self-autonomy. While critical thinking enables us to face the meaninglessness of the world, it also encourages us to design our own rules of life, the rules by which we choose to live (Taylor 2007).
Strikingly, the participants often spoke of processes of critical awareness of themselves and their own subjectivity. In a way, they stated that the fact that they were aware of their own subjectivity would allow them to come closer to the truth. The 'absolute' character of religion, which Alexander mentioned above, would prevent religious persons from thinking 'outside the box' or allowing themselves to think or reflect on worldviews that are different from their own. In a way, the perceived religious ignorance about or denial of subjectivity were seen as forces that took religious persons further away from the objective 'truth'. Anna, (22) who was raised in a Jewish community in Australia, described how it felt to step away from the religious community 'bubble' she grew up in. To her, the notion of subjectivity was linked to empowerment and autonomy.

Maybe it's a sense of autonomy... and although it is quite affected by family and schools that I went to, but I think I always had this feeling of kind of being connected to a bigger picture instead of just... I heard this quote by this poet that I really liked and she said she was brought up with the notion of a blind man touching an elephant, and like you know, you're always touching something much bigger than you think it is.

The Indian parable of the 'blind men and an elephant' gives an insight into this feeling that 'no-one's worldview can ever be complete. The story describes a group of blind men who each touch a different part of an elephant such as the tusk, trunk or leg. Since they each only touch one part of the elephant, they find themselves in complete disagreement over what the elephant is like (Wang 1995). It is a tale about the significance of subjectivity and the impossibility of attaining total truth. According to Anna, the more critical we are, even of our own subjectivity, the deeper we can move towards a sense of greater understanding of the world around us. By moving away from the 'religious bubble' that she grew up in, she came to realize more and more that objective 
truth does not exist. This relates strongly to ideas inherited from the 18th century that religion can counteract the freedom of the self-critical individual. In this way, atheism becomes more and more appealing (Manschreck 1976).

However, whereas most interviewees highly valued their ability to think and reflect critically, some interviewees also perceived the idea that they were 'second-guessing' everything as a curse. They felt that religion could provide support and answers which would lighten a certain burden. Although in their eyes, religious people were less self-reflective than non-religious people, this 'ignorance' could be seen as bliss. Frances (23), a German student who was studying for a Master's in Business, identified as a strong atheist. He stated that those who he perceived to be 'stupid people' were definitely more happy than intelligent people; according to him, these 'stupid people' did not have the urge to think about the big questions in life and were in this way released from a certain heaviness. He furthermore stated that if his assumptions were indeed true, he would rather be ignorant. Furthermore, Damien (20), who consciously chose to be an atheist because this, for him, was linked to intelligence and critical self-awareness, also described critical thinking as a source of a dark heaviness. He then claimed that religion would allow one to live a happier life, "cause you have an answer, you don't go looking for an answer, because you already have it. You can just live your life." In this way, the tension between the desire to be critical and ignorant is clearly expressed. While the idea that religion keeps one ignorant was sometimes seen as negative, some participants also expressed the feeling that, at certain moments in their lives, they longed for the ignorance and simple happiness they thought religion could provide. Religion, in their eyes, would allow them to live in the answer', instead of in an atmosphere of uncertainty and doubt that would sometimes prevent them from simply enjoying their lives.

\section{Something and Nothing}

The third duality we encountered in our data was a tension between the 'belief in 'something' and 'nothing at all'. While analyzing the interviews, we discovered that although all participants identified as non-religious, only three of them stated that there existed absolutely nothing beyond the physical world. For instance, Frances (23) stated that he was happy to enjoy life in this moment and after death would just "rot away in the ground". Furthermore, Alexander (25) stated that he did not need spirituality or the idea of a supernatural being or power in order to live a rich life. The world as it is, he stated, was already enough.

I don't miss being religious. I mean: just this! This is enough! And I think that if you can let go of this [idea that there must be 'something'], you could also enjoy the world more as it is.

For these participants, it felt as if they had found meaning in simply the physical world around them, without the existence of a higher being or spiritual energy. In this way, life in itself became 'something. These experiences connect to Taylor's (2007) notion of another condition of non-religious experience in which we live our lives as well and fully as possible, without ever focusing on the supernatural. It is the idea that human life, here and now, is the goal. Looking for transcendent explanations beyond this life would mean running away from the reality of our earthly existence (Taylor 2007). In fact, most participants stated that 'life in itself' could already provide them with a sense of meaning. 
These 'moments of purpose' were often connected to creativity, personal achievements or a sense of connection to other people. Together with the majority of our interviewees, Dean (23), a German student whose parents had both left their church, emphasized the importance of human connection at various points during the interview. In line with the findings of Day's (2009) study, he stated that he found a sense of meaning and support in many forms of human relationships, whether it was just having fun together, having a discussion, or 'sharing body warmth'.

It depends on the relationships. And in all these, like, themes, I would say, I would really have this moment like: "yes, nice! I am happy that I have this person in this moment in this way."

What was striking about the findings was that almost every interviewee related this sense of meaning to the importance of enjoying 'this moment', here and now. We can understand this significance of presence as related back to the notions of individual autonomy and meaning-making. The participants each held the belief that they were left to create their sense of meaning and purpose in their present life; there was no paradise to come, only the present moment (Taylor 1992).

In a way, almost all interviewees explicitly or implicitly said that they could have an experience of 'meaning-making' without the idea of a God. Tom (18) was baptized and had joined religious classes in church although his parents were both agnostics. When he grew older, he let go of his religious beliefs. Tom explained during his interview that he and his brothers had a discussion about religiosity with their grandmother. When she mentioned over Christmas that she was disappointed they did not go to church with her, Tom and his brothers tried to explain why, to them, religion was not the source of meaning.
So we had to tell her that we find courage and things in other things... sometimes we experience, it's not a religious feeling, but when you're at a good concert, and you're there with other people and you just feel that it's perfect. That really is the feeling that she is looking for with a God, I think. We really had to explain that we don't need to believe in a God, but that we can understand how she thinks. (...) It was a long discussion. She was really emotional. It hurt her, I think. (...) But she got fine with it, because she... we told her that we experience things, but we don't just call it God. It's because we can be happy without the concept of a God, by just finding support in each other, in moments.

In this quote, Tom emphasizes that he and his grandmother were actually looking for the same feelings, the same moments of 'feeling that it is perfect', but that the source of these experiences was just different. During the discussion with his Grandmother, he stated that he also experienced 'things' but just did not give the name 'God' to them. In similar ways, many of the other interviewees stated that by finding support in moments, in this life here and now, the belief in God or anything supernatural was made redundant by them. This ties in with Taylor's (2007) account of the different lived experiences of non-religiosity. According to Taylor, people start developing new ways of developing their moral or spiritual life, in which they can experience a certain 'richness' or 'fullness' in activities or moments: at these particular, almost 'magical' instances, life appears to be fuller and more complete than it normally seems to be.

However, all but the three interviewees who stated that there was nothing beyond the physical world implicitly expressed a certain unwillingness to accept the idea of absolute nothingness. Although at the beginning of the interviews, some clearly stated that there was absolutely nothing, they significantly questioned this idea once the discussion went into the consequences of this 
nothingness. For many, the idea that there was absolutely nothing after death was experienced as incomprehensible, very sad, or simply unbearable.

Tom was the only interviewee who made this inner turmoil very explicit. Although he emphasized at various points that he did not need the idea of a God in order to find meaning in life, he contradicted himself when he started talking about an afterlife. During the interview, he spoke about the funeral of his great-aunt, which had taken place a couple of weeks earlier. As she was his first close family member to die, he experienced this as an important turning point in his life. In the interview, he describes how he linked her death to the idea of an afterlife.

I pictured her in an afterlife. I was there when they put her in the grave. And it was a family grave, and there were already four coffins in it... and I thought it was really sad if that's it. They put your body in there and you just lay there and until you're gone, one day. I thought that was really sad, so I hoped for her that her soul, or how do you call it, would go to a place where she is comforted, sees her parents again. It was also raining and I was in the train, and it was raining and I thought: she's now just in that grave, and it's raining on her, that is really sad, to go that way. So I hope that she has a place to be. That's not how you wanna... end. (...) I think I know there is nothing, but that thought makes me a little sad.

Tom states that he knows there is nothing, but still hopes there is an afterlife because the idea that nothing will remain of you when you die is very depressing. In a way, his rationality is contradicted by his feelings of sadness caused by the idea of an infinite nothing after death, a tension that is reflected in Sartre's notion of despair in the absence of God or an afterlife.
Similarly, Damien (20), who identified as a 'full-on atheist', began to doubt his earlier assumptions when he started talking about the idea that there was absolutely nothing. "People who really just believe that it's just there and no one created it... I can't do that either. Something must have created all this." Damien's words echo those of Franceska at the beginning of this report, as she described the idea of nothing as impossible to comprehend. To think that there is absolutely nothing 'out there' can be as incomprehensible as the idea of a God. For Damien too, his ideas on atheism are contradicted by his unwillingness to accept the emptiness that is nothingness.

Following Damien's reflections, it was interesting to see how he related the idea of a 'creator' of the world (who would in turn have to be created by another creator) to mathematical equations. He compared the idea of the infinite sequence of creators to ideas of larger infinities. In the same sense, all interviewees who expressed a certain notion of the spiritual tended to relate these ideas to scientific proof. For instance, Amanda (22) linked the idea of an afterlife to the law of physics that energy cannot be lost.

I think there is something really after death. Purely again, in terms of physics, energy can't be lost and if we consider the human soul... it's pure information and energy that every living creature carries, so energy in nature can't be lost. So it must go somewhere, like somewhere... your physical body might die but everything that you gathered throughout your life, like energy, it has to go somewhere, it might go into the soil when they bury you in the ground... but it has to go somewhere.

She states that although one's physical body might die, the 'energy' of the human soul is impossible to lose and that it 'must go somewhere. In this sense, she uses natural scientific ideas in order to 
verify her spiritual notions. This appeared in a number of other interviews as well, as all participants who spoke of their spiritual beliefs such as human connection, spirits, afterlife and life energy linked these ideas to natural science.

These findings connect strongly to the value of critical thinking discussed in the previous section. As participants reflected on science as the crucial tool for critical, autonomous thinkers and the antithesis of blind faith in a religion on one hand, it was particularly interesting to note that spirituality on the other hand could exist hand in hand with an empirical view on the world. Even more, scientific proof was seen to strengthen the spiritual experiences described by some of our interviewees. In this way, it became possible to be both spiritual and critically reflexive. These findings could be an explanation for the increasing number of people who relate to different notions of spirituality in contemporary society. The value of self-autonomy, which is central to the ideals of the Enlightenment, is also very present in modern spiritual movements.

All in all, the spiritual 'something', which is often perceived as the experience of something beyond the world around us, was brought back to the physical world by the way in which our participants related their spiritual views to science. Although natural science and spirituality are often considered as disassociated from one another, our interviewees related both within the empirically accessible realm.

\section{Conclusion: the dualities within the experience of non-religiosity}

This study aimed to investigate how students who identify as non-religious experience this non-religiosity and give meaning to their lives. For our participants, being non-religious meant that God or any divine being, who could provide answers and create purpose did not exist. Interestingly, from this point of departure, three main dualities emerged in our data, each relating to one another.
The idea that there was no God or definite purpose in life led to a certain experience of empowerment and freedom. Through the exercise of their own free will, students felt that they were able to create, make and will their own sense of being in the world. In fact, their answers reflected Sartre's notion that human beings are only what they make and will themselves to be. Consequently, each person is also fully responsible for what he or she is, something that was repeatedly emphasized by our participants, who related this sense of responsibility to a feeling of power and autonomy, which came with a certain sense of loneliness. The idea that there was no-one 'out there' whom they could rely on related to feelings of futility, despair and abandonment. Furthermore, the idea that one is fully responsible for what one is came with a certain heaviness and fear.

All participants connected the idea of being non-religious with their ability to think and reflect critically on themselves and the world around them. Because the participants mainly saw religious believers as blindly following religious dogma, they themselves felt empowered by their critical and rational stance towards the world. However, many simultaneously experienced the ability to think critically as a burden. The interviewees' responses reflected the idea that the critical thinker is, in a way, 'cursed' to question everything that he or she encounters. Being ignorant, or even 'blind' to the world as it is, was sometimes longed for and seen as a blessing.

Furthermore, the participants reflected on the tension they experienced between the belief in 'something' and 'nothing'. The majority of the participants did not state that there was absolutely 'nothing', for the idea of nothingness was experienced as sad or incomprehensible. Some interviewees identified as spiritual, or spoke of spiritual experiences. Interestingly, however, they 'validated' most of their ideas about spirituality with reference to scientific groundings. In this way, spirituality in fact became more aligned with the values of rationality and an empirical stance towards the world. Spirituality was, in a sense, brought back to the 
material world. Furthermore, the emphasis on the individual within contemporary notions of spirituality meant that spirituality and individual autonomy could go hand in hand, relating back to Sartre's and Taylor's notions of creating one's own meaning in life (Taylor, 2007).

These findings relate to Vincett and Woodhead's (2009) analysis of New Age spirituality, in which the individualism and consumerism of modern times are reflected in the phenomenon of a certain kind of 'idea shopping', in that people develop their own individual sense of meaning, which reflects their unique combination of spirituality and natural sciences. However, our research only scraped the surface of the emergence and significance of spirituality in the context of contemporary (consumer) society. Prospective qualitative research delving more deeply into the manifestations of the experiential realms of spirituality in today's society would be a recommended point of departure for future studies seeking to understand the nature and role of spirituality in contemporary societies. Furthermore, the tension between scientific thought and religiosity that our interviewees reported could also inspire for future research. For instance, it would be interesting to interview natural scientists about their ideas of meaning-making. Perhaps inner conflicts that lie beneath the common, almost 'logical' acceptance of non-religiosity would emerge.

All in all, the themes discussed reflected a duality or inner tension within the experience of being non-religious. Our participants related in varying degrees back to this tension between freedom and emptiness, empowerment and unbearable heaviness. It is within these tensions that we can move towards a richer understanding of the experience of the non-religious. The significance of this research does not lie in questioning the future of religiosity and non-religiosity in contemporary society, but rather in exploring the tensions within the lived experience of the non-religious. We are ultimately left questioning: what does this inner turmoil mean for the ways in which we live our daily lives? What are the consequences of this way of living on a broader societal level, for instance in the realms of politics, education and family and friendship? And, finally, these experiences of non-religiosity could point to a shift from a lived experience in which the individual aims to 'find' or 'discover' the essence or purpose in life, to one in which the individual first exists and encounters the world, and then, within this existence, 'creates' his or her own essence or purpose. This may be a shift from asking, 'what is the meaning of life?' to asking, 'how can we, ourselves, create our meaning in life?'. 


\section{Acknowledgements}

We would like to thank each of the interviewees for their openness and willingness to share their experiences and ideas. Our sincere thanks to Dr. Ulrike Mueller, Dr. Martha Radice, and the editors of the Journal for Undergraduate Ethnography for all their guidance in developing our research. Finally, we would like to thank Prof. Andrew Metcalfe for inspiring us through his ways of teaching both about ethnographic research and the beauty of life.

\section{REFERENCES}

Auxier, Randal, ed. "Introduction." The Personalist Forum 3(2): 85-89. Accessed January 15, 2016. https://www.pdcnet.org/pdc/bvdb.nsf/purchase?openform\&fp=persfo rum\&id=persforum_1987_0003_0002_0085_0089.

Bruce, Steve, and Tony Glendinning. 2010. “The Secular Rules: The Public Place of Religion in Britain.” In Political Studies Association Conference Proceedings. Proceedings of Political Studies Association Conference, Washington, DC. www.psa. Ac.Uk/journals/pdf/5/2010/1332_1300.pdf.

Fischer, Kurt Rudolf. 1964. “The Existentialism of Nietzsche’s Zarathustra.” Daedalus 93 (3): 998-1016.

Goodman, Kathleen M., and John A. Mueller. 2009. "Invisible, Marginalized, and Stigmatized: Understanding and Addressing the Needs of Atheist Students." New Directions for Student Services, 125: 55-63.

Hanegraaff, Wouter J. 2009. "New Age Religion”. In Religions in the Modern World: Traditions and Transformations, edited by Linda Woodhead, 340-356. London: Routledge.

Hatab, Lawrence J. 1987. "Nietzsche, Nihilism and Meaning.” The Personalist Forum 3(2): 91-111.

Hesse-Biber, Sharlene Nagy. 2016. The Practice of Qualitative Research: Engaging Students in the Research Process. 3rd ed. Boston: SAGE Publications.

Israel, Jonathan Irvine. 2006. "Enlightenment! Which Enlightenment?” Journal of the History of Ideas 67(3): 523-45.

Manschreck, Clyde L. 1976. "Nihilism in the Twentieth Century: A View from Here." Church History 45(1): 85-96.

Martel-Reny, Marie-Paul. 2014. Youth, Identity and the Search for Meaning: A Qualitative Study of Religion and Spirituality among Adolescents in Contemporary Quebec. $\mathrm{PhD}$ diss., Concordia University.

McGrath, Alister E. 2004. The Twilight of Atheism: The Rise and Fall of Disbelief in the Modern World. New York: Doubleday.

Nietzsche, Friedrich Wilhelm. 2010 (1909). Thus Spoke Zarathustra. n.p.: Feedbooks.

O'Brien, Karen. 2010. “The Return of the Enlightenment.” The American Historical Review 115(5): 1426-435.

Sartre, Jean-Paul. 2007 (1948). Existentialism and Humanism. London: Methuen. 
Taylor, Charles. 1992. The Ethics of Authenticity. Cambridge, MA: Harvard University Press, --- 2007. A Secular Age. Cambridge, MA: The Belknap Press of Harvard University Press.

Uskoković, Vuk. “The Metaphorical Model: The Bridge between Science and Religion.” 2010. Journal for Interdisciplinary Research on Religion and Science, 6: 11-33. Wang, Randy. 1995. "The Blind Men and the Elephant." The Blind Men and the Elephant. March 19, 1995. Accessed June 7, 2016. http://www.cs.princeton.edu/ rywang/berke ley/258/parable.html.

Vincett, Giselle and Linda Woodhead, 2009. "Spirituality." In Religions in the Modern World: Traditions and Transformations, 2nd ed., edited by Linda Woodhead and Hiroko Kawanami, 319-37. London: Routledge. 